\title{
Impacts of fuel feeding methods on the thermal and emission performance of modern coal burning stoves
}

\author{
Riaz Ahmad ${ }^{1,2,3}$, Yuguang Zhou ${ }^{1,2,3^{*}}$, Nan Zhao ${ }^{1,2,3}$, Crispin Pemberton-Pigott ${ }^{3,4}$, \\ Harold John Annegarn ${ }^{3,4}$, Muhammad Sultan ${ }^{5}$, Renjie Dong ${ }^{1,2,3,6}$, Xinxin Ju ${ }^{7}$ \\ (1. Bioenergy and Environmental Science and Technology Laboratory, College of Engineering, China Agricultural University, Beijing \\ 100083, China; \\ 2. Key Laboratory of Clean Renewable Energy Utilization Technology, Ministry of Agriculture and Rural Affairs, Beijing 100083, China; \\ 3. National Center for International Research of BioEnergy Science and Technology, Ministry of Science and Technology, Beijing 100083, \\ China; \\ 4. School of Geo- and Spatial Sciences, Private Bag X6001, North-West University, 2520 Potchefstroom, South Africa; \\ 5. Department of Agricultural Engineering, Bahauddin Zakariya University, Bosan Road, Multan 60800, Pakistan; \\ 6. Yantai Institute, China Agricultural University, No. 2006 Binhai Zhonglu, Laishan District, Yantai, Shandong Province 264670, China; \\ 7. Shandong Sino-March Environmental Technology Co., Ltd., Yantai 264006, China)
}

\begin{abstract}
The extensive use of traditional cooking and heating stoves to meet domestic requirements creates a serious problem of indoor and outdoor air pollution. This study reports the impacts of two fuel feeding methods - front-loading and top-loading on the thermal and emissions performance of a modern coal-fired water-heating and cooking stove using a contextual test sequence that replicates typical patterns of domestic use. Known as a low-pressure boiler, when this stove was fueled with raw coal, the findings indicate that front-loading the fuel, which devolatilizes the new fuel gradually, produced consistently higher space heating efficiency and lower emission factors than top-loading the same stove, which devolatilizes new fuel all at once. Comparing the performance at both high and low power gave the similar results: front-loading with raw coal produced consistently better results than top-loading. The average water heating efficiency when front-loading was $(58.6 \pm 2.3) \%$ and $(53.4 \pm 1.8) \%$ for top-loading. Over the sixteen-hour test sequence, front-loading produced $22 \%$ lower emissions of $\mathrm{PM}_{2.5}(3.9 \pm 0.6) \mathrm{mg} / \mathrm{MJ}_{\mathrm{NET}}$ than top-loading (4.7 \pm 0.9$) \mathrm{mg} / \mathrm{MJ}_{\mathrm{NET}}$. The same pattern was observed for carbon monoxide and the $\mathrm{CO} / \mathrm{CO}_{2}$ ratio. $\mathrm{CO}$ was reduced from $(5.0 \pm 0.4) \mathrm{g} / \mathrm{MJ} \mathrm{NET}_{\text {to }}(4.1 \pm 0.5) \mathrm{g} / \mathrm{MJ}_{\mathrm{NET}}$. The combustion efficiency $\left(\mathrm{CO} / \mathrm{CO}_{2}\right.$ ratio) improved from $(8.2 \pm 0.8) \%$ to $(6.6 \pm 0.6) \%$. Briquetted semi-coked coal briquettes are promoted as a raw coal substitute, and the tests were replicated using this fuel. Again, the same pattern of improved performance was observed. Front loading produced $3.5 \%$ higher heating efficiency, $10 \%$ lower $\mathrm{CO}$ and a $0.9 \%$ lower $\mathrm{CO} / \mathrm{CO}_{2}$ ratio. It is concluded that, compared with top loading, the manufacturers recommended front-loading refueling behavior delivered better thermal, emissions and combustion performance under all test conditions with those two fuels.
\end{abstract}

Keywords: stoves, front-loading, top-loading, refueling, domestic coal, thermal efficiency, $\mathrm{PM}_{2.5}$ emissions, semi-coked coal briquettes

DOI: $10.25165 /$ j.ijabe.20191203.3880

Citation: Ahmad R, Zhou Y G, Zhao N, Pemberton-Pigott C, Annegarn H J, Sultan M, et al. Impacts of fuel feeding methods on the thermal and emission performance of modern coal burning stoves. Int J Agric \& Biol Eng, 2019; 12(3): 160-167.

\section{Introduction}

Coal is a major energy carrier in most countries. Important domestic uses of such energy are cooking and space heating ${ }^{[1,2]}$. It is estimated that some three billion people use solid fuels in the

\section{Received date: 2018-02-06 Accepted date: 2019-04-30}

Biographies: Riaz Ahmad, $\mathrm{PhD}$ candidate, research interests: biomass engineering, Email: riaz@cau.edu.cn; Nan Zhao, PhD candidate, research interests: biomass engineering, Email: nan.zhaoca@outlook.com; Crispin Pemberton-Pigott, Adjunct Professor at China Agricultural University, research interests: stoves and labour-enhancing equipment, Email: crispinpigott@outlook.com; Harold John Annegarn, PhD, Associate Professor at North-West University, research interests: energy and sustainable Mega cities, improvement and testing of domestic combustion stoves and air pollution reduction, Email: hannegarn@gmail.com; Muhammad Sultan, PhD, Assistant Professor, research interests: energy and environment engineering, Email: muhammadsultan@bzu.edu.pk; Renjie Dong, Professor, research interests: biomass engineering, Email: rjdong@cau.edu.cn; Xinxin Ju, Engineer, research interests: biomass engineering, Email: jxx0617@126.com.

*Corresponding author: Yuguang Zhou, PhD, Associate Professor, China Agricultural University, No.17 Qinghua East Road, Haidian District, Beijing 100083, China. Tel/Fax: +86-10-62737885, Email: zhouyg@cau.edu.cn. form of coal, crop residues, charcoal, wood, peat, and coke $\mathrm{e}^{[3]}$. Chinese residential consumption was approximately $90 \mathrm{Mt}$ of coal in $2011^{[4]}$. More than $50 \%$ of the energy in urban households and $22 \%$ in rural households was provided by coal burned in stoves and small low-pressure boilers (LPB) ${ }^{[5,6]}$.

Consumption of coal and coal-based fuels for domestic cooking and space heating is a major source of greenhouse gases (GHGs) and atmospheric pollutants such as particular matter with a diameter of less than 2.5 micrometers $\left(\mathrm{PM}_{2.5}\right)$, carbon monoxide $(\mathrm{CO})$, nitrogen oxides $\left(\mathrm{NO}_{\mathrm{X}}\right)$, black carbon, and hydrogen sulfide $\left(\mathrm{H}_{2} \mathrm{~S}\right)$. Some of those pollutants cause significant human health problems even in low concentrations. Household air pollution (HAP) is considered among the top environmental risks_in China as is the case in many other developing countries ${ }^{[7]}$. According to the World Health Organization (WHO), an estimated 4.3 million people a year die prematurely from illness attributable to HAP created by the inefficient combustion of solid fuels ${ }^{[8]}$. It has been reported that low-quality coal is a significant cause of air pollution in China ${ }^{[9-12]}$. For example, raw coal combusted by rural households was reported to be responsible for $26 \%$ of urban and 
$32 \%$ of rural ambient $\mathrm{PM}_{2.5}$ during the winter heating season in $\mathrm{Xi}^{\prime}{ }{ }^{[13]}$. Those pollutants do not necessarily originate from inherent coal properties but are more often from the incomplete combustion of fuels in appliances not well-matched to the fuel properties. User behaviors can exacerbate under-performance arising from the mismatch between stoves and fuels.

There have been several projects to study and distribute modern stoves and fuels in rural China attempting to mitigate these pollution problems ${ }^{[14,15]}$. However, to be widely adopted, the features of a stove design must match the cultural and functional needs of the users. Thus, new standards have been implemented that consider thermal efficiency, cooking efficiency, quantification of emissions and a ten-hour fire endurance requirement ${ }^{[16,17]}$. Meeting these cultural demands and the new standards requires that operators understand the correct usage of stove features, including refueling techniques. Traditional domestic stoves in this sector have a hole on top that functions both as a cooking station and a refueling port. Some modern stoves that were presented on the market after 2000 feature a separate upper front door for refueling and increasingly common feature. Such a front-loading stove might (correctly) be refueled through the upper door on the front, or (incorrectly) through the top cooking hole - a well-known cultural behavior.

This study investigates the influence of these two alternative operators refueling behaviors, front loading and top loading, that might affect the emissions and thermal efficiency of such a modern domestic coal stove. The fire burns in a fundamentally different manner with these two methods. Top-loading places cold fuel on a hot coke base, leading to rapid devolatilization of the whole added batch, and tends to lead to anoxic, flameless gasification of at least part of the added fuel. Front-loading tends to feed the fire from one side which devolatilizes the new fuel gradually. This tends not to create a flameless condition, usually with better combustion conditions releasing a greater fraction of the embedded energy. The evaluation was performed using two common fuels, raw coal, and semi-coked coal briquettes. The assessments were performed using an online, real-time stove performance testing system developed at the China Agricultural University's Biomass Energy Stove Testing (BEST) Laboratory. The stove selected was an $11.7 \mathrm{~kW}$-rated coal-fired low-pressure boiler (LPB) with integrated cooking, suited to the requirements of typical rural households in China. The results of those tests can be used to inform policy and product selection for the residences in the agricultural sector of China.

\section{Materials and methods}

\subsection{Fuel preparation}

Two fuels, raw coal passing through a $40 \mathrm{~mm}$ screen, and 50 $\mathrm{mm}$ diameter semi-coked coal briquettes, were used during the tests (Figure 1). The fuels were stored in an environment with stable humidity.

The ultimate and proximate analysis of the fuels was performed by the North China Electric Power University using relevant Chinese standards: (NY/T 1881.1-2010) ${ }^{[18]}$ - Industrial Standard of the People's Republic of China, (GB/T 28731-2012) ${ }^{[19]}$ and $(\mathrm{GB} / \mathrm{T} 28734-2012)^{[20]}$ - National Standards of the People's Republic of China.

\subsection{Testing procedures}

The tests were performed at the BEST Laboratory at China Agricultural University (CAU), Beijing. The Hebei Farmer contextual testing sequence was used. It was derived from field observations and used in the Hebei Clean Heating Project in $2017^{[21]}$. The testing sequence is sixteen hours long and represents the typical cooking and heating behaviors of rural farmers in Hebei Province, China (Figure 2).

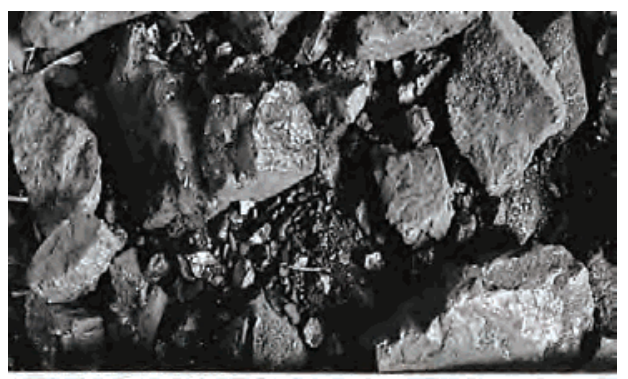

56789101234567892012345

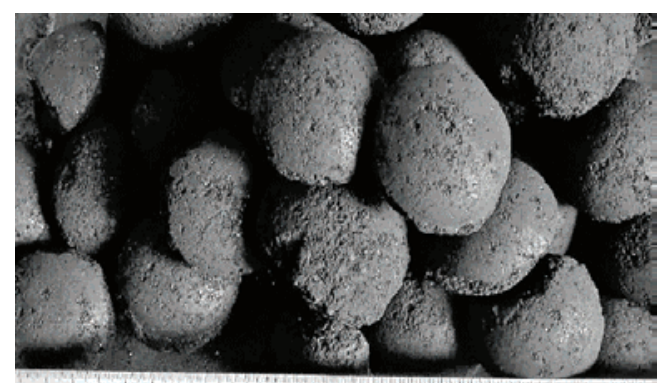

789101234567892012345678930

Figure 1 Raw coal (left) and semi-coked coal briquettes (right)

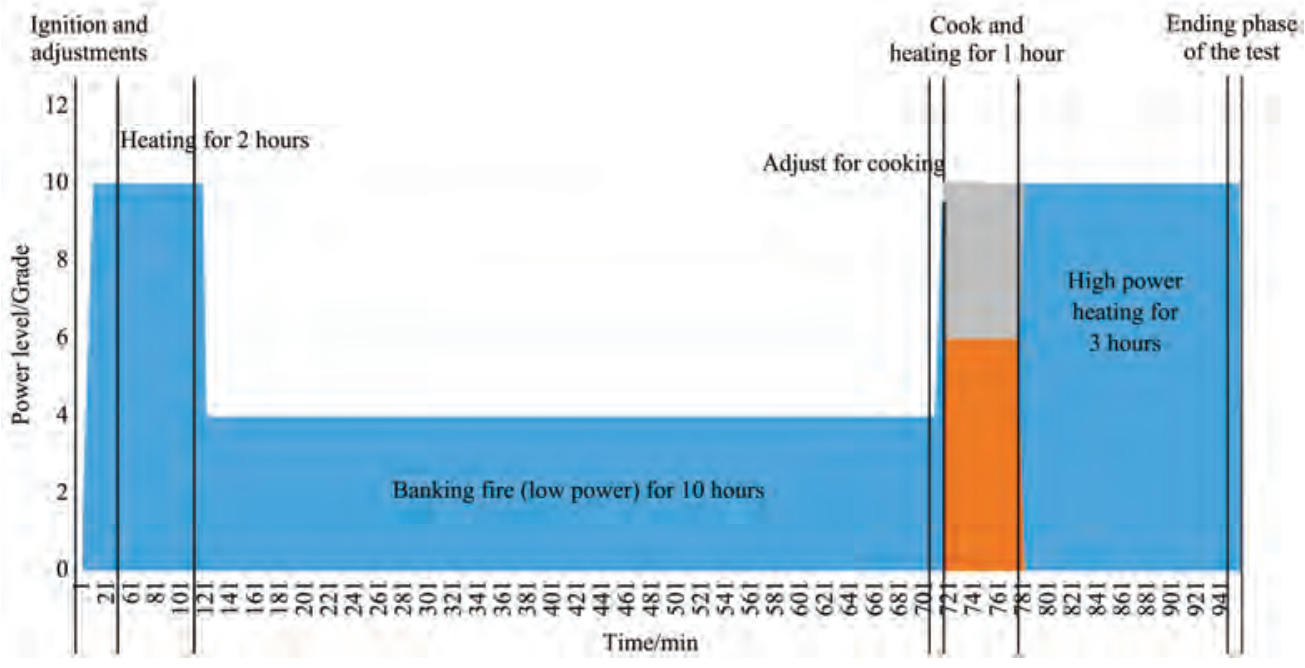

Figure 2 16-hour contextual test sequence 
The poorest combustion conditions are most common when igniting, refueling or when ramping from low power heating to high power cooking. Banking the fire from high to low power sometimes produces high emissions. Increasing the number of power changes or the number of cooking events will affect the emitted mass. To establish "comparative performance", a full range of typical behaviors should be replicated during a standard test sequence. If the ignition is once per heating season, the ignition emissions should be ignored. The performance parameters reported are the thermal efficiency, combustion efficiency and emission factors for $\mathrm{PM}_{2.5}$ and $\mathrm{CO}$ expressed in unit mass per Megajoule of energy delivered into the circulating water. Measurements were automatically logged at least every $10 \mathrm{~s}$ and stored for analysis. The schematic diagram of the stove used for two fuel feeding option shown in Figure 3.

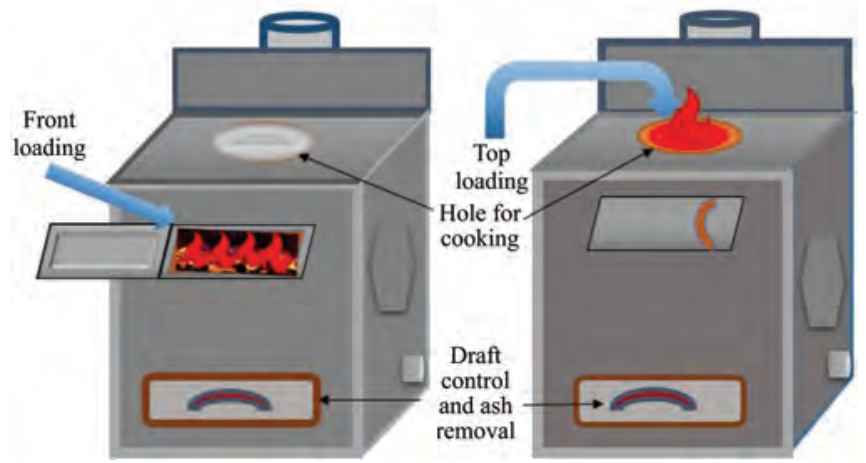

Figure 3 Stove with two fuel feeding options

\subsection{Test apparatus}

Temperatures were measured with K-type thermocouples logged once per second. An ultrasonic flowmeter was used to determine the water flow rate through the heat exchanger $[\mathrm{L} / \mathrm{s}]$. A gas analyzer (MRU MGA5/Vario Plus, Germany) was used to measure flue gas concentrations. It has a non-dispersive infrared (NDIR) sensor for measuring carbon dioxide $\left(\mathrm{CO}_{2}\right)$ and electrochemical cells for trace gases: $\mathrm{O}_{2}, \mathrm{CO}, \mathrm{NO}_{\mathrm{x}}$, and $\mathrm{SO}_{2}$. The particulate matter was measured in a diluted air stream using a
DustTrak DRX aerosol monitor (Model 8533) which consecutively reports $\mathrm{PM}_{1}, \mathrm{PM}_{2.5}, \mathrm{PM}_{4}$, and $\mathrm{PM}_{10}$. The dilution system was fashioned after that of the SeTAR Centre (University of Johannesburg, South Africa $)^{[22]}$. A sample drawn continuously from the flue is diluted by $\mathrm{CO}$ - and $\mathrm{CO}_{2}$-free dry air. The manually variable dilution ratio is provided by comparing simultaneous measurements of $\mathrm{CO}_{2}$ in the flue gas and the diluted sample stream.

The stove testing system is shown in Figure 4. Before each test, the function of the instruments was checked. A zero calibration of the Dusttrak particle counter was performed before each test. The gas analyzers were zero calibrated before every test. A total of twelve tests were conducted - three replications of each combination of fuel and loading behavior.

The level of dilution by the particle diluter can be adjusted at the control panel by altering the flow rate of the dilutant gas, permitting the measurement of a wide range of smoke concentrations. The dilution ratio can be varied from 3:1 to 100:1 as required, to keep the concentration within the operating limits of the particle counter $\left(0.001-150 \mathrm{mg} / \mathrm{m}^{3}\right)$. The dilutant is air scrubbed in an absorber to produce the zero air containing low concentrations of $\mathrm{CO}(<1 \mathrm{ppm}), \mathrm{CO}_{2}(<1 \mathrm{ppm})$ and water vapor $(<1 \mathrm{ppm})$. The dilutant dehydrates the particles and enhances the condensation of particles from the gaseous phase by cooling. The integrated mass from the Dusttrack continuous recordings is compared with the mass collected on a $37 \mathrm{~mm}$ filter attached to the outlet to derive the particle density factor for the particles (conversion from particle number to mass). The particle detector has an optical measurement system. Above 50\% humidity, the presence of water vapor affects the optical diameter of smoke particles, so it is necessary to monitor the relative humidity. The dilution ratio is adjusted during a test to maintain the relative humidity within the range of $15 \%-30 \%$. The dilution level is thus determined by two considerations: keeping the maximum PM concentration under the $150 \mathrm{mg} / \mathrm{m}^{3}$ limit or optimizing the detection limit at low concentrations, and simultaneously keeping the relative humidity under $30 \%$.

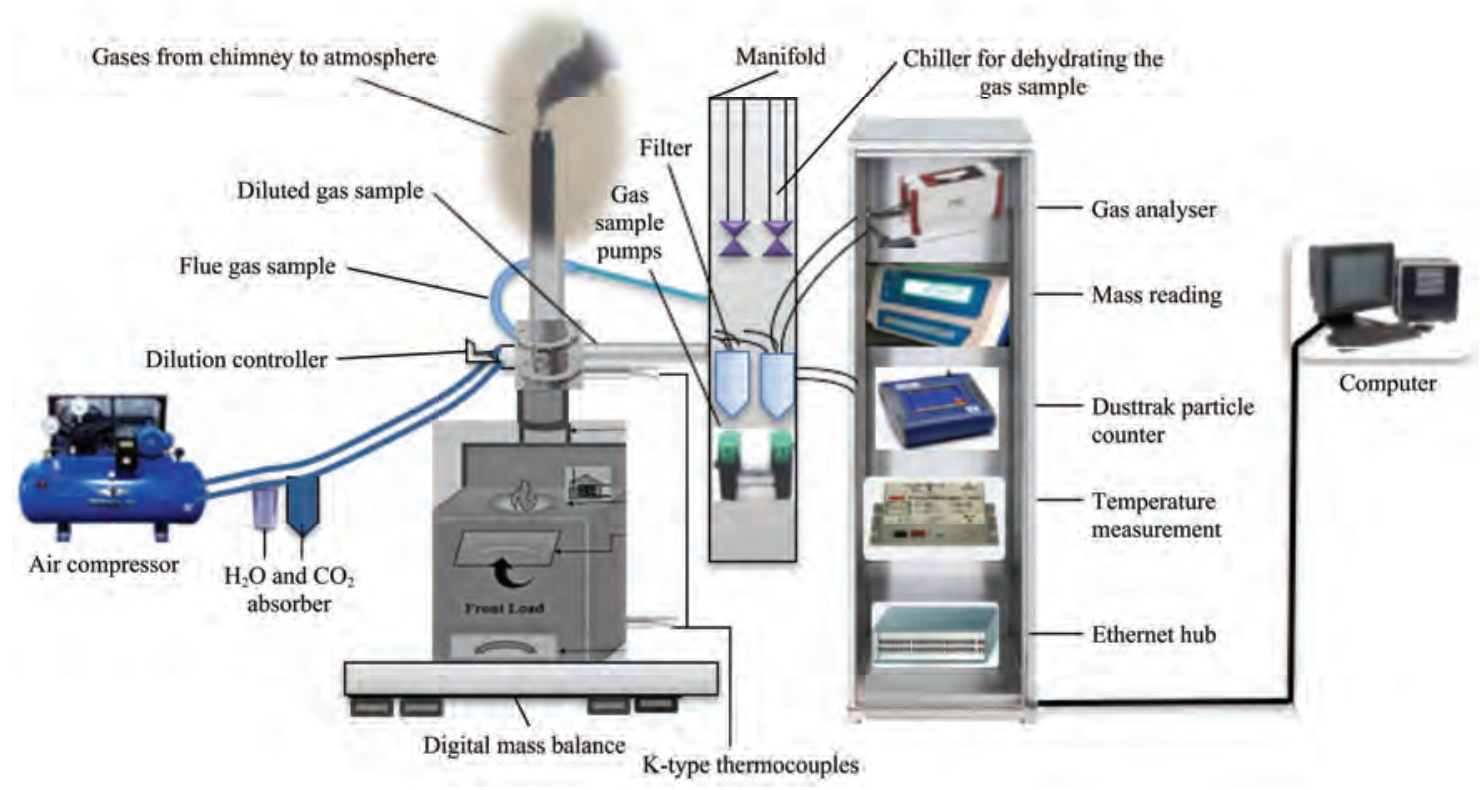

Figure 4 Online testing system

The dilution ratio for each interval is required for the calculation of the emitted mass of PM. The $\mathrm{CO}_{2}$ in the dilution tunnel is compared with the flue gas concentration and the dilution level obtained per recording interval.

At the start of a test, the stove was placed on the electronic mass balance, together with a pre-weighed load of kindling and 
fuel. The fire was ignited with paper and small pieces of coal from the pre-weighed load. Measurements were recorded every $10 \mathrm{~s}$. Parameters recorded included mass of the stove system, space heating heat exchanger inlet and outlet water temperatures, temperature of the cooking pot contents, inlet and outlet temperatures of the cooking pot heat exchanger, flow rates of the coolant through the heat exchangers, all PM channels and trace gas emissions from the flue and from the diluter, ambient and diluted gas humidity, and the ambient air temperature and pressure. During the high-power portion of the test sequence, the flow of coolant through the space heating heat exchanger was adjusted as needed to keep the outlet temperature under $70^{\circ} \mathrm{C}$. The concentrations of trace gases $\mathrm{H}_{2}, \mathrm{C}_{x} \mathrm{H}_{y}, \mathrm{SO}_{2}, \mathrm{NO}, \mathrm{CO}, \mathrm{CO}_{2}, \mathrm{O}_{2}$ were measured directly from flue while in the diluter measurements included $\mathrm{CO}_{2}, \mathrm{H}_{2} \mathrm{O}, \mathrm{H}_{2} \mathrm{~S}$. The calculated outputs include the cooking and space heating efficiency, several emission factors and the combined cooking and heating efficiency according to Beijing Municipal Standard (DB11/T540-2008) General Technical Specification of Domestic Biomass Stove/Boiler (Beijing Municipal Bureau of Quality and Technical Supervision, 2008 $)^{[16]}$. The fire was set and ignited according to the manufacturer's instructions.

The quantity of fuel adequate for the test is estimated using the following equation:

$$
M_{f}=3.6\left\{\frac{\left(D_{t} P_{r N E T}\right)}{L H V_{f} \eta_{r}}\right\}+1.1
$$

where, $M_{f}$ is the mass of the fuel set aside, $\mathrm{kg} ; 3.6$ converts $\mathrm{J} / \mathrm{s}$ to $\mathrm{kJ} / \mathrm{h} ; D_{t}$ is the testing duration, $\mathrm{h} ; P_{r N E T}$ is rated heating power, $\mathrm{kW}_{\mathrm{NET}} ; L H V_{f}$ is the lower heating value of the fuel as received (AR), MJ $/ \mathrm{kg} ; \eta_{r}$ is the rated high power thermal efficiency, $\% ; 1.1$ was added as a safety margin so as not to run out before the test ended.

\subsection{Calculated values}

The performance parameters were calculated using the equations listed below.

The heat gained by the LPB heat exchanger $\left(Q_{H E x}\right)$ and the water contained within it is calculated as:

$$
Q_{H E x}=\left\{\left(C_{p H E x} / C_{p W} \times m_{H E x}+m_{W H E x}\right) \times C_{p W} \times \Delta \bar{T}_{H E x}\right\}
$$

where, $C_{p H E x}$ is the specific heat capacity of the heat exchanger; $C_{p W}$ is the specific heat capacity of water, $\mathrm{J} / \mathrm{g} ; m_{H E x}$ is the mass of the heat exchanger, g; $m_{W H E x}$ is the mass of the water in the heat exchanger, $\mathrm{g} ; \Delta \bar{T}_{H E x}$ is the change in average the temperature of the water in the heat exchanger, ${ }^{\circ} \mathrm{C}$, which is calculated using Equation (3):

$$
\Delta \bar{T}_{H E x}=\left[\frac{T_{2}+T_{1}}{2}\right]_{f}-\left[\frac{T_{2}+T_{1}}{2}\right]_{i}
$$

where, the item with subscript $f$ is the final time; the item with subscript $i$ is the initial time; $T_{1}$ is inlet temperature, ${ }^{\circ} \mathrm{C} ; T_{2}$ is the outlet temperature, ${ }^{\circ} \mathrm{C}$;

Heat gained by the water flowing through the heat exchanger per recording interval $\left(Q_{j W H E x}\right)$ is calculated as:

$$
Q_{j_{W H E x}}=\left\{\left(C_{p W} \times\left(T_{2}-T_{1}\right) \times\left(t_{2}-t_{1}\right) \times F R_{\text {WHEx }}\right)\right\}
$$

where, $\left(t_{2}-t_{1}\right)$ is the recording interval, s; $F R_{W H E x}$ is the water flow rate through the heat exchanger, $\mathrm{g} / \mathrm{s}$.

The total heat gained by the water flowing through the heat exchanger during the test $\left(Q_{W H E x}\right)$ is calculated as:

$$
Q_{W H E x}=\sum_{j-1}^{n}\left\{F_{r} \times C_{p W} \times\left(T_{2}-T_{1}\right) \times\left(t_{2}-t_{1}\right)\right\}
$$

where, $F_{r}$ is the flow rate of water through cooking pot heat exchanger $\mathrm{g} / \mathrm{s} ; n$ and $j-1$ from measurement 1 to measurement $\mathrm{n}$ is the total heat gained.

The total heat gained by the heat exchanger system $\left(Q_{T H}\right)$ is calculated as:

$$
Q_{T H}=Q_{H E x}+Q_{W H E x}
$$

The heat gained by the cooking pot heat exchanger and the water contained within $\left(Q_{c}\right)$ it is calculated as:

$$
Q_{C}=\left\{\left(C_{p C E x} / C_{p W} \times m_{C E x}+m_{W C E x}\right) \times C_{p W} \times \Delta \bar{T}_{C E x}\right\}
$$

where, $C_{p C E x}$ is the specific heat capacity of the cooking pot heat exchanger; $m_{C E x}$ is the mass of the pot heat exchanger, g; $m_{W C E x}$ is the mass of the water in the pot heat exchanger, $g ; \Delta \bar{T}_{C E x}$ is the change in the average temperature of the water in the pot heat exchanger, ${ }^{\circ} \mathrm{C}$, calculated using Equation (8):

$$
\Delta \bar{T}_{C E x}=\left[\frac{T_{2}+T_{1}}{2}\right]_{f}-\left[\frac{T_{2}+T_{1}}{2}\right]_{i}
$$

where, the item with subscript $f$ is the final time; the item with subscript $i$ is the initial time.

Heat gained by the water flowing through the cooking pot heat exchanger per recording interval $\left(Q_{j W C E x}\right)$ is calculated as:

$$
Q_{j W C E x}=\left\{\left(C_{p W} \times\left(T_{4}-T_{3}\right) \times\left(t_{2}-t_{1}\right) \times F_{R_{W C E x}}\right)\right\}
$$

where, $T_{3}$ is the cooking pot heat exchanger water inlet temperature $T_{4}$ is the cooking pot heat exchanger water outlet temperature; $F_{R W C E x}$ is the water flow rate through the cooking pot heat exchanger, $\mathrm{g} / \mathrm{s}$.

The total heat gained by the water flowing through the cooking pot heat exchanger $\left(Q_{W H E x}\right)$ is calculated as:

$$
Q_{W H E x}=\sum_{j-1}^{n}\left\{F_{r} \times C_{p W} \times\left(T_{2}-T_{1}\right) \times\left(t_{2}-t_{1}\right)\right\}
$$

The heat gained by the cooking pot and its uncirculated contents per recording interval $\left(Q_{j P o t}\right)$ is calculated using Equation (11):

$$
Q_{i_{P o t}}=\left\{\left(\frac{C_{p P o t}}{C_{p W}} \times m_{P o t}+m_{W P O t}\right) \times C_{p W} \times\left(T_{2}-T_{1}\right) \times\left(t_{2}-t_{1}\right)\right\}
$$

where, $C_{p P o t}$ is the specific heat capacity of the cooking pot, J/g; $m_{P o t}$ is the mass of the pot, $\mathrm{g}$.

The total heat gained by the cooking pot and its uncirculated contents $\left(Q_{p}\right)$ is calculated as:

$$
Q_{p}=\sum_{j-1}^{n}\left\{\left(\frac{C_{p P o t}}{C_{p W}} \times m_{\text {Pot }}+m_{W P o t}\right) j \times C_{p W} \times\left(T_{2}-T_{1}\right)\right\}
$$

where, $j$ is heat gained by uncirculated water in cooking pot $\mathrm{J} / \mathrm{g}$.

The total energy gained by the cooking system $\left(Q_{T C}\right)$ is calculated as:

$$
Q_{T C}=Q_{C E x}+Q_{W C E x}+Q_{p}
$$

The total energy gained by the heating and cooking system $\left(Q_{T}\right)$ is calculated as:

$$
Q_{T}=Q_{T H}+Q_{T C}
$$

The total chemical energy available $\left(U_{T}\right)$ from the fuel fed into the stove during the test (Equation (15)):

$$
U_{T}=B_{K} L H V_{K}+B_{F} L H V_{F}
$$

where, $B_{K}$ is the mass of kindling materials, $\mathrm{kg} ; L H V_{K}$ is the lower heating value of the kindling materials as received, $\mathrm{MJ} / \mathrm{kg} ; B_{F}$ is the mass of fuel, $\mathrm{kg} ; L H V_{F}$ is the $L H V$ of the fuel as received, $\mathrm{MJ} / \mathrm{kg}$.

The fractional energy utilization is calculated as the ratio of $U_{T}$ - the useful heat delivered by the stove - to $Q_{T}$ - the total heat available from the fuel fed. The pre-weighed fuel was placed on the scale before starting the test. The test continued for sixteen hours from ignition to completion. The one-hour cooking phase commenced twelve hours after ignition. The cooking efficiency is based on readings from that period. Changes in mass over 
selected intervals were determined from the mass balance data and were interpreted to be the mass of fuel consumed during the respective space heating or cooking phases.

The cooking efficiency $\left(\eta_{c}\right)$ was calculated as:

$$
\eta_{c}=\frac{Q_{T C}}{U_{T}} \times 100
$$

The space heating efficiency $\left(\eta_{h}\right)$ is calculated as:

$$
\eta_{h}=\frac{Q_{T H}}{U_{T}} \times 100
$$

The system (overall) $\left(\eta_{t}\right)$ efficiency was calculated using Equation (18):

$$
\eta_{t}=\frac{Q_{T}}{U_{T}} \times 100
$$

The total volume of diluted gases emitted $\left(V_{D i l \sim 1}\right)$ is calculated as:

$$
V_{\text {Dil } \sim 1}=V_{\text {Sto }} \times m_{\text {fuel }} \times \lambda
$$

where, $V_{S t o}$ is the stoichiometric volume of gases produced by the combustion of $1 \mathrm{~kg}$ of fuel (AR), $\mathrm{m}^{3} ; m_{\text {fuel }}$ is the mass of fuel fed, $\mathrm{kg} ; \lambda$ is the total air demand factor providing both used and unused oxygen.

The dilution ratio $(D R)$ between the flue gases and the diluted gas sample is calculated as:

$$
D R=\left(\mathrm{CO}_{2 \text { flue }} / \mathrm{CO}_{2 \text { Diluted }}\right)
$$

The total mass of PM reported during the sampling interval $\left(T P M_{2.5}\right)$ is calculated using Equation (21):

$$
T P M_{2.5}=P M_{2.5} \times D R \times V_{\text {Dil } ~}
$$

where, $P M_{2.5}$ is the total measured mass of particles reported by the instrument.

The $\mathrm{PM}_{2.5}$ emission factor $\left(E F_{P M_{2.5}}\right)$ is calculated as:

$$
E F_{P M_{2.5}}=\frac{T P M_{2.5}}{Q_{T}}
$$

where, $Q_{T}$ is the total useful heat energy, MJ, from Equation (14)

The average mass concentration of $\mathrm{CO}$ is calculated as:

$$
C O(m)=p p m(v) \times 0.0012334
$$

where, $\operatorname{ppm}(v)$ is the average $\mathrm{CO}$ concentration expressed on a volumetric basis, ppm; and 0.0012334 is the conversion constant for $\mathrm{CO} p p m(v)$ to $C O(m), \mathrm{g} / \mathrm{m}^{3}$.

The total mass of $\mathrm{CO}$ emitted is calculated as:

$$
T C O=C O(m) \times V_{D i l \sim 1}
$$

The $\mathrm{CO}$ emission factor $\left(E F_{C O}\right)$ is calculated as:

$$
E F_{C O}=\frac{T C O}{Q_{T}}
$$

The percentage increase in thermal efficiency $\left(\eta_{T I}\right)$ is calculated as:

$$
\eta_{T I}=\left(\frac{\eta_{T L}-\eta_{F L}}{\eta_{F L}}\right) \times 100 \%
$$

where, $\eta_{T L}$ is the thermal efficiency of top-load, $\% ; \eta_{F L}$ is the thermal efficiency of top-load \%.

The percentage decrease in $\mathrm{CO}, \mathrm{CO} / \mathrm{CO}_{2}$, and $\mathrm{PM}_{2.5}$ is calculated using Equations (27)-(29), respectively.

$$
C O_{D}=\left(\frac{C O_{T L}-C O_{F L}}{C O_{F L}}\right) \times 100 \%
$$

where, $C O_{D}$ is the decrease in $\mathrm{CO}, \% ; C O_{T L}$ is the $\mathrm{CO}$ emission of top-load $\mathrm{g} / \mathrm{MJ}_{\mathrm{NET}} ; C_{F L}$ is the $\mathrm{CO}$ emission of front-load $\mathrm{g} / \mathrm{MJ}_{\mathrm{NET}}$.

$$
\left(\mathrm{CO} / \mathrm{CO}_{2}\right)_{D}=\left(\frac{\mathrm{CO} / \mathrm{CO}_{2}-\mathrm{CO} / \mathrm{CO}_{2}}{\mathrm{CO} / \mathrm{CO}_{2}}\right) \times 100 \%
$$

where, $\left(\mathrm{CO} / \mathrm{CO}_{2}\right)_{D}$ is the decrease in $\mathrm{CO} / \mathrm{CO}_{2}$ ratio, \%; $\mathrm{CO} / \mathrm{CO}_{2}$ is the $\mathrm{CO} / \mathrm{CO}_{2}$ emission of top-load \%; $\mathrm{CO} / \mathrm{CO}_{2}{ }_{F L}$ is the $\mathrm{CO} / \mathrm{CO}_{2}$ emission of front-load $\%$.

$$
P M_{2.5_{D}}=\left(\frac{P M_{2.5_{T L}}-P M_{2.5_{F L}}}{P M_{2.5}}\right) \times 100 \%
$$

\begin{tabular}{|c|c|c|c|c|c|}
\hline Test indicators & Unit & Equipment & Precision & Measuring range & Test principle \\
\hline Fuel mass loss & $\mathrm{g}$ & Straw FCN-V10 & $\pm 0.1 \%$ & $30-600 \mathrm{~kg}$ & Double beam sensor electronic scale \\
\hline $\begin{array}{l}\text { Flue gas }\left(\mathrm{O}_{2}, \mathrm{CO}_{2}, \mathrm{CO}, \mathrm{NO}_{\mathrm{x}}\right. \\
\left.\mathrm{SO}_{2}\right) \text { concentration }\end{array}$ & ppm & MRU Vario Plus & $\pm 0.1 \%$ & $\begin{array}{c}\mathrm{O}_{2}, \mathrm{CO}_{2}, \mathrm{CO}, \mathrm{NO}_{\mathrm{x}} \\
\mathrm{SO}_{2}=0-10000 \mathrm{Vol} \% \mathrm{EC} \\
\mathrm{CO}_{2}=0-30 \% \text { (NDIR) }\end{array}$ & $\mathrm{CO}_{2}$ used NDIR, others use EC sensors \\
\hline Flow Rate & $\mathrm{m} / \mathrm{s}$ & MRU Vario Plus & $\pm 0.1 \%$ & $1-100 \mathrm{~m} / \mathrm{s}$ & Using pitot tube \\
\hline Particulate matter & $\mathrm{mg} / \mathrm{m}^{3}$ & $\begin{array}{l}\text { DustTrak DRX Aerosol } \\
\text { Monitor } 8533 \text { Desktop }\end{array}$ & $\begin{array}{l} \pm 0.1 \% \text { of reading of } \\
\quad 0.001 \mathrm{mg} / \mathrm{m}^{3}, \\
\text { whichever is greater }\end{array}$ & $0.001-150 \mathrm{mg} / \mathrm{m}^{3}$ & $\begin{array}{l}\text { Simultaneously measure size-segregated } \\
\text { mass fraction concentrations corresponding } \\
\text { to } \mathrm{PM}_{1}, \mathrm{PM}_{2.5} \text {, respirable, } \mathrm{PM}_{10} \text { and total } \\
\mathrm{PM} \text { size fractions }\end{array}$ \\
\hline $\begin{array}{l}\text { Analysis of flue gas } \\
\text { concentration of diluents: } \\
\mathrm{CO}_{2}, \mathrm{H}_{2} \mathrm{O}, \mathrm{H}_{2} \mathrm{~S}\end{array}$ & ppm & $\begin{array}{l}\text { DP00112/ DP00118 } \\
\text { TESTO } 6681+6614\end{array}$ & $\pm 2 \% \mathrm{FS}$ & 0-30 $000 \mathrm{ppm}$ & $\begin{array}{l}\mathrm{CO}_{2} \text { using NDIR, } \mathrm{H}_{2} \mathrm{~S} \text { using EC sensors, } \\
\mathrm{H}_{2} \mathrm{O} \text { using a humidity sensor }\end{array}$ \\
\hline Determination of water flow & $\mathrm{mL} / \mathrm{s}$ & TUF-2000P & $\pm 1 \%$ & $0 \pm 10 \mathrm{~m} / \mathrm{s}$ & Ultrasonic flow measurement \\
\hline Temperature & ${ }^{\circ} \mathrm{C}$ & Thermocouple & $\pm 0.2^{\circ} \mathrm{C}$ & $-270^{\circ} \mathrm{C}-1260^{\circ} \mathrm{C}$ & Thermo-electric effect \\
\hline
\end{tabular}

where, $P M_{2.5_{D}}$ is the decrease in $P M_{2.5}$ emission \%; $P M_{2.5_{T L}}$ is the $P M_{2.5}$ emission from top-load $\mathrm{mg} / \mathrm{MJ}_{\mathrm{NET}} ; \quad P M_{2.5}$ iL is the $P M_{2.5}$ emission from front-load $\mathrm{mg} / \mathrm{MJ}_{\mathrm{NET}}$.

\subsection{Equipment specifications}

A catalogue of testing indicators, instruments and testing principles is given in Table 1. Sixteen-hour duration tests were conducted to evaluate the performance of the stoves, combining the relevant Chinese standard methods with modifications from observed local behaviors. The testing sequence comprises various stages informed by observing the cooking and heating practices of rural Chinese users.

Table 1 Description of test indicators, equipments, and testing principles

Note: NDIR = Non-dispersive infra-red; MV = Measured value; FS = Full scale reading; EC = Electrochemical. 


\section{Results and discussion}

\subsection{Ultimate analysis of the fuels}

Both fuels were analyzed for their elemental composition, moisture content, volatile matter fraction and higher heating value (HHV) from which the lower heating value (LHV) was calculated. The moisture content of the raw coal $(9.04 \%)$ was higher than that of the semi-coked coal briquettes $(3.5 \%)$, determined on a wet weight basis. The volatiles content of the briquettes was low (Table 2). The nitrogen content of the briquettes was higher than that of the raw coal. The efficiency of the stove when top-loaded with raw coal $(54.7 \% \pm 1.8 \%)$ was significantly lower than when top-loaded with briquettes $(62.7 \% \pm 2.7 \%)$. This demonstrates that the fuel can strongly affect stove performance. Fuels analyses are provided in Table 2 .

Table 2 Proximate analysis as received and ultimate analysis after drying

\begin{tabular}{lcc}
\hline \multicolumn{1}{c}{ Component } & Raw coal & Semi-Coke Briquettes \\
\hline Proximate (as received) & & \\
\hline Moisture $_{\mathrm{AR}}$ & $9.04 \%$ & $3.50 \%$ \\
Ash $_{\mathrm{AR}}$ & $5.67 \%$ & $15.70 \%$ \\
Volatile $_{\mathrm{sAR}}$ & $27.1 \%$ & $10.2 \%$ \\
Fixed Carbon $_{\mathrm{AR}}$ & $58.14 \%$ & $70.60 \%$ \\
LHV $_{\mathrm{AR}} / \mathrm{MJ}^{-1} \mathrm{~kg}^{-1}$ & 17.41 & 25.89 \\
\hline Ultimate (after drying) & & \\
\hline Ash & & $16.60 \%$ \\
Carbon & $6.23 \%$ & $60.30 \%$ \\
Hydrogen & $67.50 \%$ & $4.05 \%$ \\
Nitrogen & $4.54 \%$ & $0.84 \%$ \\
Sulphur & $0.94 \%$ & $0.33 \%$ \\
Oxygen & $0.38 \%$ & $18.20 \%$ \\
\hline
\end{tabular}

\subsection{Thermal performance}

The test results showed that front-loading the fuel produced a higher thermal efficiency in all cases, even when combustion efficiency was good. Thermal efficiencies are presented in Figure 5. The front-loading thermal efficiency burning raw coal was $(54.7 \pm 1.8) \%$ and $(62.7 \pm 2.7) \%$ for briquettes. The top-loading thermal efficiency burning raw coal was $(49.2 \pm 1.8) \%$ and $(58.1 \pm 2.1) \%$ for briquettes. Regarding fuel savings, front-loading the stove saved $(7.3 \pm 3.4) \%$ for briquettes and $(10.1 \pm 2.5) \%$ for raw coal. Increase in thermal efficiency of front load method as compared to top load are shown in Table 3.

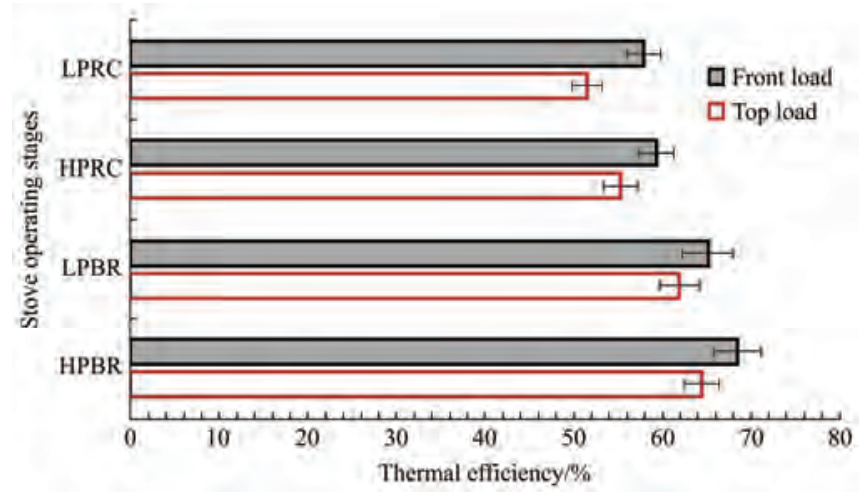

Note: $\mathrm{HPBR}=$ high power briquettes; $\mathrm{LPBR}=$ low power briquettes; HPRC $=$ high power raw coal; LPRC $=$ low power raw coal. Error bars are standard deviations from three replications.

Figure 5 Thermal performance of the front-loading versus top-loading for low and high power and two types of fuel
Table 3 Increase in thermal efficiency and decrease in $\mathrm{CO}$, $\mathrm{CO} / \mathrm{CO}_{2}$, and $\mathrm{PM}_{2.5}$ of front load method as compared to top load (\%)

\begin{tabular}{|c|c|c|c|c|c|}
\hline \multicolumn{2}{|c|}{ Performance indices } & HPBR & LPBR & HPRC & LPRC \\
\hline \multicolumn{2}{|c|}{ Increase in thermal efficiency } & 6.21 & 5.17 & 7.25 & 12.42 \\
\hline \multicolumn{2}{|c|}{ Decrease in $\mathrm{CO}$} & 23.90 & 26.77 & 20.48 & 23.27 \\
\hline \multicolumn{2}{|c|}{ Decrease in $\mathrm{CO} / \mathrm{CO}_{2}$} & 28.30 & 6.16 & 33.94 & 14.57 \\
\hline \multicolumn{2}{|c|}{ Decrease in $\mathrm{PM}_{2.5}$} & 23.61 & 12.64 & 17.60 & 66.71 \\
\hline \multirow{4}{*}{$\begin{array}{c}\text { Standard } \\
\text { deviation } \\
\text { (top-loading } \\
\text { method) }\end{array}$} & Thermal efficiency & 1.95 & 2.26 & 1.93 & 1.73 \\
\hline & $\mathrm{CO}$ & 0.36 & 0.35 & 0.36 & 0.46 \\
\hline & $\mathrm{CO} / \mathrm{CO}_{2}$ & 0.72 & 0.84 & 0.81 & 0.89 \\
\hline & $\mathrm{PM}_{2.5}$ & 0.80 & 0.65 & 0.83 & 0.86 \\
\hline \multirow{4}{*}{$\begin{array}{c}\text { Standard } \\
\text { deviation } \\
\text { (front-loadin } \\
\mathrm{g} \text { method) }\end{array}$} & Thermal efficiency & 2.67 & 2.85 & 1.96 & 1.86 \\
\hline & $\mathrm{CO}$ & 0.19 & 0.25 & 0.47 & 0.45 \\
\hline & $\mathrm{CO} / \mathrm{CO}_{2}$ & 0.51 & 0.62 & 0.59 & 0.63 \\
\hline & $\mathrm{PM}_{2.5}$ & 0.87 & 0.54 & 0.65 & 0.53 \\
\hline
\end{tabular}

\subsection{Emission measurement}

3.3.1 Particular matter $\left(\mathrm{PM}_{2.5}\right)$

The average $\mathrm{PM}_{2.5}$ emitted when top-loaded was $4.6 \pm 0.8$ $\mathrm{mg} / \mathrm{MJ}_{\mathrm{NET}}$ burning raw coal while when burning briquettes, it was $2.9 \pm 0.7 \mathrm{mg} / \mathrm{MJ}_{\mathrm{NET}}$. Front-loading was better for burning both raw coal $\left(2.8 \pm 0.6 \mathrm{mg} / \mathrm{MJ}_{\mathrm{NET}}\right)$ and briquettes $\left(2.5 \pm 0.7 \mathrm{mg} / \mathrm{MJ}_{\mathrm{NET}}\right)$ (Figure 6). Analysis of the real-time testing data that the $\mathrm{PM}_{2.5}$ emission numbers were higher for top-loading than front-loading because the fuel dropped directly on fire and disturbed fuel already in the combustion zone.

In a previous study, $\mathrm{Li}$ et al. ${ }^{[23]}$ found $\mathrm{PM}_{2.5}$ was $53 \pm 6$ $\mathrm{mg} / \mathrm{MJ}_{\mathrm{NET}}$ when top-loading raw coal and $23 \pm 5 \mathrm{mg} / \mathrm{MJ}_{\mathrm{NET}}$ top-loading briquettes in a modern stove, a reduction of $57 \%$. This study showed a reduction of $(26.2 \pm 6.8) \%$ achieved at high power when substituting semi-coked coal briquettes for raw coal. The decrease in $\mathrm{PM}_{2.5}$ of front load method as compared to top load are shown in Table 3.

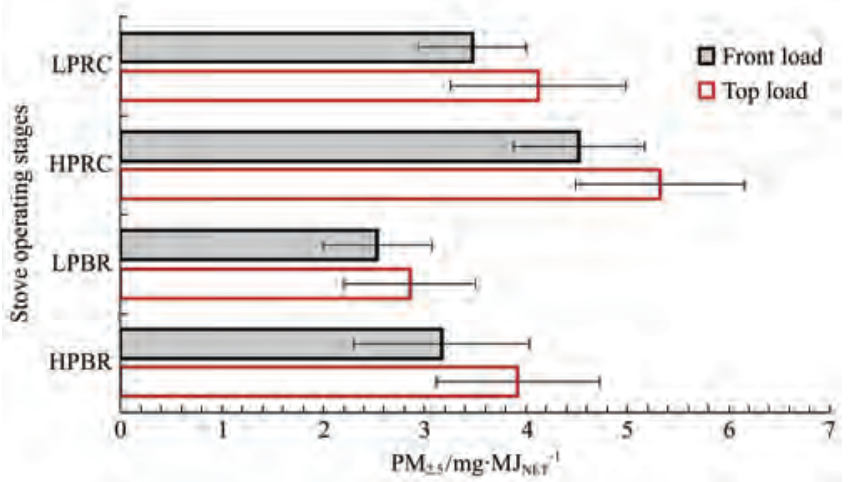

Figure $6 \mathrm{PM}_{2.5}$ mass of per Megajoule delivered, front-loaded versus top-loaded for the two fuels at low and high power

\subsection{2 $\mathrm{CO} / \mathrm{CO}_{2}$ ratio}

The lower the $\mathrm{CO} / \mathrm{CO}_{2}$ ratio, the more complete the combustion of carbon. The $\mathrm{CO} / \mathrm{CO}_{2}$ ratios during high power for front-loaded raw coal was lower than for top-loaded raw coal: $(5.7 \pm 0.7) \%$ versus $(7.6 \pm 0.8) \%$ (Figure 7 ). The $\mathrm{CO} / \mathrm{CO}_{2}$ ratios for both feeding methods were found to be lower during high power combustion. The $\mathrm{CO} / \mathrm{CO}_{2}$ ratio for top-loading was lower during high power $(7.63 \pm 0.81) \%$ and $(6.80 \pm 0.72) \%$, and higher during low power, $(8.7 \pm 0.9) \%$ and $(7.2 \pm 0.8) \%$ burning raw coal and briquettes respectively. The $\mathrm{CO} / \mathrm{CO}_{2}$ ratios for front-loading was lower than when top-loaded for both fuels and all operating 
conditions. The $\mathrm{CO} / \mathrm{CO}_{2}$ ratios for front-loading at high power for raw coal and briquettes was, respectively, $(5.7 \pm 0.6) \%$ and $(5.3 \pm 0.5) \%$ while at low power it was $(7.6 \pm 0.6) \%$ and $(6.7 \pm 0.6) \%$. It was observed that for both refueling behaviors the stove operating at high power had relatively good $\mathrm{CO} / \mathrm{CO}_{2}$ ratios, but the combustion quality declined slightly as the burn rate decreased due to an increasing level of excess air. The results for decrease in $\mathrm{CO} / \mathrm{CO}_{2}$ of front load method as compared to top load are shown in Table 3.

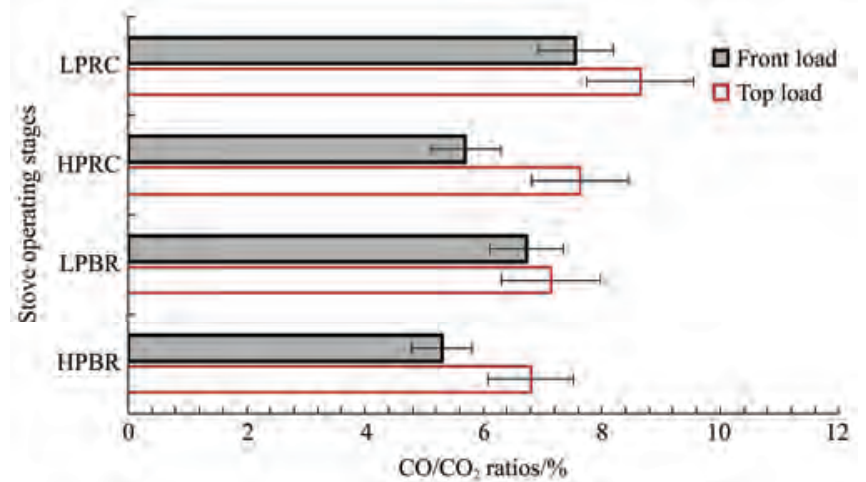

Figure $7 \mathrm{CO} / \mathrm{CO}_{2}$ ratios of front-loaded versus top-loaded for low and high power and two fuels

The results supported previous findings that the $\mathrm{CO} / \mathrm{CO}_{2}$ ratio is affected by several factors including air-fuel ratio, burn rate, combustion temperature, combustion efficiency, thermal efficiency, residence time in the combustion chamber and flame turbulence $^{[24-27]}$

Makonese $^{[28]}$ observed that the low combustion efficiency during ignition and in the smouldering phase, the $\mathrm{CO} / \mathrm{CO}_{2}$ ratio was poor at $15 \%$, indicating a need for further design changes to improve the combustion efficiency.

\subsubsection{CO emission factors}

The CO emission factor for front-loading found to be lower than the top-loading. The minimum emission factors were $2.0 \pm 0.2 \mathrm{~g} / \mathrm{MJ}_{\mathrm{NET}}$ at low power and $2.9 \pm 0.2 \mathrm{~g} / \mathrm{MJ}_{\mathrm{NET}}$ at high power when front-loading the briquettes. When top-loaded, this increased to $3.6 \pm 0.4 \mathrm{~g} / \mathrm{MJ}_{\mathrm{NET}}$ at high power and $2.4 \pm 0.3 \mathrm{~g} / \mathrm{MJ}_{\mathrm{NET}}$ at low power. Both loading methods produced a higher $\mathrm{CO}$ emission factor burning raw coal, but still, front-loading was significantly lower than the top-loading as shown in Figure 8. The decreases in $\mathrm{CO}$ of front load method as compared to top load are shown in Table 3.

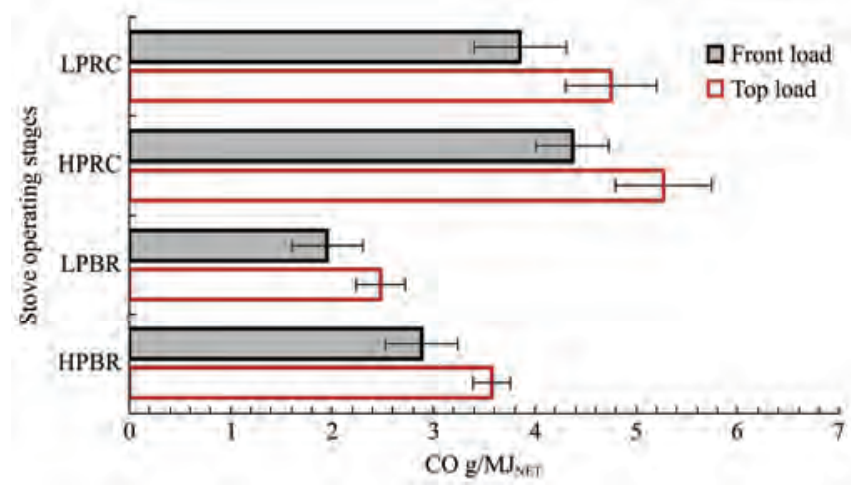

Figure $8 \mathrm{CO}$ emission factors for front-loading versus top-loading refueling for low and high power and two fuel types

\section{Conclusions}

This study investigated the effects of fuel feeding methods on thermal efficiencies and emissions of a modern cooking and heating stove burning semi-coked coal briquettes and raw coal. Sixteen-hour contextual tests representing typical behavior patterns were conducted to evaluate stove performance using a real-time detection system. The results showed that when the fuel was fed into the front of the stove, it invariably produced better in performance than when top-loaded. When burning semi-coked coal briquettes, the front-loading method delivered a higher average thermal efficiency $(66.7 \pm 3.8) \%$ and the lowest emissions of $\mathrm{PM}_{2.5} 2.9 \pm 1.0 \mathrm{mg} / \mathrm{MJ}_{\mathrm{NET}}$ and $\mathrm{CO} 2.4 \pm 0.3 \mathrm{~g} / \mathrm{MJ}_{\mathrm{NET}}$.

On the other hand, it was observed that fuel type also influenced the performance. It is concluded that $50 \mathrm{~mm}$ semi-coked coal briquettes gave better performance than randomly sized raw coal. The front-loading method delivered a higher thermal efficiency, saving fuel, and contributing to a cleaner environment.

Additional experiments were conducted using a similar stove designed for top loading only. At all power levels and for both fuels, all metrics show front loading to be superior refueling behavior. We conclude that to maximize the benefits of modern stoves, user training is essential because something as elementary as how the stove is refueled can make a considerable difference to the efficiency and emissions performance.

\section{Acknowledgements}

This research was supported by the National Natural Science Foundation of China (Grant No. 51806242); the Chinese Universities Scientific Fund (No. 2019TC010); the Chinese Universities Scientific Fund - Special Project for "Double First-Class" Initiative of College of Engineering, China Agricultural University, "the Characteristics of Thermal and Mass Flow for Clean Space-heating of Rural Households using Biofuels"; the Agricultural Product Quality Inspection Bureau, Ministry of Agriculture and Rural Affairs, China, Agricultural Industry Standard Development Project - "Determination method of major atmospheric pollutants from rural household stoves" (No. 181721301092371112); the bilateral China-South Africa MoST-NRF joint project "Development of Scientifically Robust and Culturally Appropriate Metrics and Protocols for Evaluating Clean (Combustion) Cooking Stoves", sponsored by Ministry of Science and Technology, China; Investigation on South-South Cooperation in Climate Change through Clean Stove Alliance, sponsored by Ministry of Ecology and Environment and Administrative Center for China's Agenda 21 (No. 0201835).

The work was carried out by the Key Laboratory of Clean Production and Utilization of Renewable Energy, Ministry of Agriculture and Rural Affairs, China Agricultural University; National Center for International Research of BioEnergy Science and Technology, Ministry of Science and Technology, China Agricultural University; and Beijing Municipal Key Discipline of Biomass Engineering.

\section{[References]}

[1] Hou B D, Tang X, Ma C, Liu L, Wei Y M, Liao H. Cooking fuel choice in rural China: Results from microdata. Journal of Cleaner Production, 2017; 142(2): 538-547.

[2] Casillas C E, Kammen D M. The energy-poverty-climate nexus. Science, 2010; 330(6008): 1181-1182.

[3] International Energy Agency, 2002 International Energy Agency. World Energy Outlook 2002. OECD/IEA, Paris. 
[4] Department of Energy Statistics of National Bureau of Statistics of China. China energy statistical yearbook of 2012. Beijing: China Statistical Press, 2013. (in Chinese)

[5] He B, Liang L, Jiang G. Distributions of arsenic and selenium in selected Chinese coal mines. Science of the Total Environment, 2002; 296(1-3), 19-26.

[6] Liu K. The opportunities and challenges of controlling endemic arsenism in China. Chinese Journal of Endemiology, 2007; 26(1): 4-5. (in Chinese)

[7] Liu W, Shen G, Chen Y, Shen H, Huang Y, Li T, et al. Air pollution and inhalation exposure to particulate matter of different sizes in rural households using improved stoves in central China. Journal of Environmental Sciences, 2018; 63(1): 87-95.

[8] WHO. 2014. Household air pollution and health. WHO Fact sheet N 292. Updated May 2018. https://www.who.int/news-room/fact-sheets/ detail/household-air-pollution-and-health [accessed on 2019-01-02].

[9] Zhang Y X, Hao J, Zhou Y G, Zhang Z X, Chen L, Dong R J. Assessment of pollutant emissions and energy efficiency of four commercialized charcoal stoves with modified Chinese cooking stove protocol. Int J Agric \& Biol Eng, 2018; 11(2): 202-207.

[10] Zhi G, Yang J, Zhang T, Guan J, Du J, Xue Z, et al. Rural household coal use survey, emission estimation and policy implications. Research of Environmental Sciences, 2015; 28(8): 1179-1185. (in Chinese)

[11] Chai F, Xu Z, Zhi G, Luo Y, Ren Y, Ye J. Complex control measures of rural coal combustion pollution. Environmental Protection, 2016; 44(6): 15-19. (in Chinese)

[12] Chen N L, Zhang D W, Li Y T, Fan M. Residential emissions in Beijing: about $400 \times 10^{4} \mathrm{t}$. Proceedings of the National Academy of Sciences of the United States of America, 2016; 113(40): 5778-5779.

[13] Dai Q, Bi X, Song W, Li T, Liu B, Ding J, et al. Residential coal combustion as a source of primary sulfate in Xi'an, China. Atmospheric Environment, 2019; 196: 66-76.

[14] Shen G, Lin W, Chen Y, Yue D, Liu Z, Yang C. Factors influencing the adoption and sustainable use of clean fuels and cookstoves in China -A Chinese literature review. Renewable and Sustainable Energy Reviews, 2015: 51: 741-750.

[15] Smith K, Gu S, Huang K, Qiu D. One hundred million improved cookstoves in China: How was it done? World Development, 1993; 21(6):941-961.

[16] Beijing Municipal Bureau of Quality and Technical Supervision. General technical specification of domestic biomass stove/boiler. (DB11/T 540-2008). (in Chinese)

[17] National Standard of the Peoples Republic of China. General administration of quality supervision, test method for household coal and stoves. (GB/T 6412-2009). (in Chinese)

[18] Ministry of Agriculture, Peoples Republic of China. Densified biofuel test methods Part 1: General principles. (NY/T 1881.1-2010). (in Chinese)

[19] National Standard, Peoples Republic of China. Proximate analysis of solid biofuels. (GB/T 28731-2012). (in Chinese)

[20] National Standard, Peoples Republic of China. Determination of carbon and hydrogen in solid biofuel. (GB/T 28734-2012). (in Chinese)

[21] World Bank. 2015. China - Hebei Clean Heating Project (English). Washington, D.C.: World Bank Group. http://documents.worldbank.org/ curated/en/902691467992494218/China-Hebei-Clean-Heating-Project. Accessed on [2019-01-12].

[22] Robinson J, Pemberton-Pigott C, Makonese T, Annegarn H. Heterogeneous stove testing protocols for emissions and thermal performance. Proceedings of the International Conference on the Domestic Use of Energy, Cape Town, March 29-31, 2010; pp.41-48.

[23] Li Q, Jiang J, Qi J, Deng J, Yang D, Wu J, et al. Improving the energy efficiency of stoves to reduce pollutant emissions from household solid fuel combustion in China. Environmental Science Technology Letters, 2016; 3(10): 369-374.

[24] MacCarty N, Ogle D, Still D, Bond T, Roden C, Willson B. Laboratory comparison of the global-warming potential of six categories of biomass cooking stoves. Aprovecho Research Center, Oregon: Creswell; 2007.

[25] Arora P, Jain S. Estimation of organic and elemental carbon emitted from wood burning in traditional and improved cookstoves using controlled cooking test. Environmental Science Technology, 2015; 49(6): 3958-3965

[26] MacCarty N, Ogle D, Still D, Bond T, Roden C. A laboratory comparison of the global warming impact of five major types of biomass cooking stoves. Energy Sustainable Development, 2008; 12(2): 56-65.

[27] Venkataraman C, Habib G, Eiguren-Fernandez A, Miguel A H, Friedlander S K. Residential biofuels in South Asia: Carbonaceous aerosol emissions and climate impacts. Science, 2005; 307(5714): 1454-1456.

[28] Makonese T. Heterogeneous stove testing methods for the evaluation of domestic solid-fuel cookstoves. International Energy Journal, 2018; 18: 191-206. 